\title{
Journal Writing in the EFL Classroom of Nepal
}

\author{
Gyanendra Yadav
}

\begin{abstract}
Based on classroom research, this paper explores the use of journal writing as a multi-purpose tool in the English as a foreign language (EFL) classroom of Nepal. In the first part of the paper, the author introduces readers to the concepts of journal writing and also shares his own experience of writing reflective journals as a university student. This section also explains how he applied the same task among children in the classroom. The second part of the paper discusses the opportunities and challenges of using journal writing in the EFL classroom. The results suggest that journal writing can serve multiple purposes in the English language classroom. It is found to be an effective technique to make students reflect on what they have learnt and enhance their writing skill as well.
\end{abstract}

Keywords: Journal writing, EFL (English as a foreign language), Reflective practice, Language development, Nepal

\section{Background}

In the first class of the Academic Writing course in my Master of Education program, we were asked, "Have you ever written anything except in examination?" The whole class remained silent for a while. I was forced to reflect on my journey as a writer and realized that I did not have good writing experience besides taking notes, summarizing and answering the questions given in the textbooks. In fact, the writing practice I had done till then was mostly for preparing and passing examinations. The facilitator noticed that most students lack the writing habit in the Nepali context. Thus, he assigned us to write a reflective journal regularly, which continued throughout my master's degree program in the writing course and other courses as well. After two years of such practice, when I looked back at the journals I wrote during this period, I felt that I had significantly improved my writing. I could express myself efficiently, record my critical moments as a teacher, and be reflective in my writing. More importantly, writing became a habit, not just a medium of writing an examination paper as it was in the past.

As language teachers, we might face situations where EFL learners are found demotivated to write and, hence, unable to develop a writing habit. In this context, 
journal writing can contribute to improve students' writing skills for the sake of writing, expressing, learning and being reflective in the language classroom. I realized the importance of journal writing and introduced the concept in the school where I have been teaching as an English teacher. After one year of such writing practice, I analyzed the significance of writing journals in the language classroom. With this backdrop, I share my experience of using journal writing in the EFL context of Nepal, where writing appears to be a neglected skill in most cases.

\section{Concept of journal writing}

Before I share my experience of using reflection in the EFL classroom, first, I will discuss the theoretical component. Journal writing, also known as journaling, diary writing, and reflective journal, is a means of recording daily activities, learning, and feeling through writing. Denne- Bolton (2013) defines journal writing as a written conversation between a teacher and students on a particular topic, including reactions and reflections on what they have been reading and hearing. He also adds that journal writing provides students ample opportunity to practise writing regularly without any fear. Journal writing can be taken "both as means and an end" (Ur, 1991) of writing as it serves the dual purposes of writing: "writing for writing" and "writing for learning" (Harmer, 2007). In other words, through journal writing, we can reflect in action, thinking during an event, and on action, the thought process after an event (Schon, 1987, as cited in Shin, 2006). In short, journal writing can help students enhance their writing skills besides being an effective tool of reflective practice for an EFL teacher.

The idea of journaling seems to be congruent with the expressivist approach, which views that writing can be developed through activities engaging in reflection, expression, and discovery (Thomas, 2017). It can be said that the more students express their ideas, emotions, and feelings in their writing, the more they get immersed in the writing process. It appears to be a kind of dialogue with oneself where students give voice to their activities, experiences, observations, events, and learning. In doing so, they are engaged in a meaningful interaction with their teacher, which in turn can help them enhance their academic performance besides developing writing skills.

Journal writing has been a fascinating area for teacher researcher to study learners' language development in kindergarten (Hipple, 1985) and elementary schools (Kintisch, 1986). Likewise, it was explored as a significant tool for developing writing skills in writing courses (Heath, 1988) as well as a variable to improve performance in different courses (Cicero, 2006). More recently, journaling is done through online blogs and is investigated as a means of voicing students' challenges (Thomas, 2017) in this technological era. Above all, most studies carried out on journal writing reveal that journaling can be an effective way to record language development in young learners, enhance writing skills and course performance, and give voice to students' challenges.

However, these studies focus on one aspect at a time and overlook the numerous purposes journal writing can serve in a language classroom. Therefore, in this 
paper, I seek to explore journal writing as a multi-purpose tool in the EFL classroom of Nepal. In the following section, I share how I used this tool in a secondary level EFL classroom of Nepal.

\section{The study}

Although journal writing is common in language teaching, it appeared to be a new strategy for teachers in my current school. We introduced journal writing as an essential component in each academic subject. We also incorporated journal writing in our testing system as a part of an internal evaluation. In the beginning of the academic year, we had a sharing session among all the teachers on how to use reflective writing in the classroom. Students were given some samples writing and were asked to write in a journal after each lesson. They were given feedback on their writings.

After a year of practice, I attempted to discuss and analyze the use of journal writing in the language classroom. The data for the present study were collected through interviews, artifacts and were supported by my observation as a journal writer and an English teacher. First, I collected reflections written by the students throughout the academic session and analyzed them. Those reflections were written by secondary level students. Then, I purposefully selected six students as participants for the interview to required information. Then, I generated different themes for the discussion and presented at the end.

\section{Importance of journal writing}

After analyzing the data, I developed four different themes under the importance of journal writing in the EFL classroom.

\section{Enhancing reflective practice}

Journal writing is found to be an effective means of reflective practice both for the students and the teachers engaged in this process. It helps students to be reflective on their learning. Most participants noted that they understand better when they write about what they learnt in the classroom. They expressed that journaling made them think about the topics they studied in the classroom. One of them stated that writing reflections enabled him to be confident about the content in the book, meaning he could get the main ideas of the lessons once he reflected on them. This understanding of my participants was in line with Baxter (2009), who believes that keeping journals makes students think about learning and clarifies their thoughts and understanding. They become better learners when they become engaged in the process of writing.

Likewise, teachers receive the opportunity to reflect on their actions and their teaching practices. After going through students' writings, they get different ideas, perspectives and feedback on teaching and learning processes in the classroom. In my own case, a participant wrote in her reflection:

Sometimes, I feel that my teacher is too much friendly with us, compared to other teachers. I and my classmates do not feel afraid of him. Our class is full of laughter, fun and activities rather than merely being attentive.

This way, we can get feedback on teaching andlearning processes inside the classroom with the help of students' journals. Another participant critically analyzed my 
classroom activity while I was teaching Malini, a famous play by Rabindranath Tagore. She stated this way:

In the beginning, my teacher wanted to make us perform the play and asked to choose the role of several characters we like. But many of us did not get motivated to do so. Then my teacher decided that we were not performing at the beginning.

When I went through this writing, I realized that drama can be better performed at the end when students have fully understood the plot and characters of the play. Journal writing assisted me in reflecting on particular plans and how they could be implemented more effectively in the future. In this sense, "journals can function as a window into the learner's mind if the teacher reads them" (Denne-Bolton, 2013, p.3.).

\section{Developing writing skill}

Teaching writing, especially to EFL learners, can be a daunting task for many teachers (Shin, 2006). This applies to the Nepali EFL context, too. In my experience, reflective journals appeared to be an effective way to practise writing skills on the part of EFL learners. My students'journal artifacts showed that they developed their writing skills as a result of journaling; they could express their ideas effectively, confidently and in an organized way. I traced the gradual development in their writing throughout an academic year. Reflective journaling not only recorded students' learning, but also reflected the development in their writing skills. Regarding how students benefitted from journal writing, a participant articulated his voice this way:
With regular practice, I expanded my vocabulary and learnt to use them appropriately. Further, I could use variety of sentences more effectively with different grammatical structures than earlier. Most importantly, I learnt to maintain the flow (coherence) of ideas in different forms of writing.

The improvements in my students' writing seem to be in line with Denne-Bolton (2013), who states that "some of these benefits (of journal writing) are increased motivation to write, greater fluency in writing, increased confidence as writers, and the ability to use writing as a means to communicate and express complex ideas" (p. 10). The practice of writing journals seems to have made their writing much better and reflective. They even learnt to use rhetorical devices like similes and metaphors. Thus, reflective journal was found helpful in enhancing the writing skill of students.

\section{An effective means of expression}

Journal writing was commonly perceived by students as a means of expression in which they could give voice to their feelings and emotions, pain and problems. Most students had a common remark that journal writing is an effective means of expression. They could express themselves freely, and their journals became a kind of memories box for them where they could deposit their feelings, emotions, and learning.

About writing a journal, a participant mentioned; "I think I can express myself better through writing reflection now. I feel that it is an interesting and easy way of practicing writing." In their reflections, I found that they were often sharing 
remarkable events like participating in different competitions, doing projects works, visiting new places, thinking about childhood memories and so on. They even recorded their critical moments, for instance, how they felt when they first made a presentation in the classroom or first sang a song in their class. It shows that journal writing seems to be a means of expression which can also promote self-understanding (Garmon, 2001) when they read their product themselves.

A few students also realized that journal writing made them feel relaxed after putting their emotions and feelings on the paper. In this regard, a participant expressed as below:

Sometime I have some secret in my heart which I do not want to share with my parents and friends but often express in my writing. When I express my emotion and feeling through writing, it makes me feel comfortable as if it has reduced my tension.

When others wrote in their journals, they considered themselves particular characters from the text they had read. For instance, a girl mentioned that she felt like Helen, a lead character in the story "The Gardener," who faced a number of obstacles in society while keeping a secret about her relation. Journaling appears to perform a cathartic function (catharsis refers to a taking away of emotions, purification and sometimes a renewal resulting from pity, sorrow, sympathy or even laughter) for some students by providing an opportunity for emotional outlet (Hipple, 1985). This supports the long-established view in psychology that writing can be a cathartic process of releasing our strong emotions.

\section{Building rapport}

Rapport, the relationship between the students and the teacher, depends on "the way we listen to and treat the student" (Harmer, 2007, p. 25). Reading students' journals can be a significant way to listen to students and understand them. A respondent put his views as following:

Sometimes teachers might not understand students in relation with their interests, feeling, emotions, and difficulties they are facing in their learning. They just make general assumption about us. But when we started submitting our journals to teachers, they read those journals and understood us better than they did before. Now they listen to us and talk in person too. It helps us to do better and keep ourselves inspired.

Journaling "creates bond of trust and understanding" (Thomas, 2017) between students and teacher. Journal writing is not only a way to improve student writing, but also a means for teachers to get to know their students and their learning processes, which helps teachers to better serve their learners' needs (Miller 2007; HansenThomas 2003; as cited in Denne-Bolton, 2013). Students' journals helped me as a teacher to respect their identity and design my tasks based on their learning styles and preferences in order to facilitate better learning.

\section{Challenges in Journal Writing}

In my experience, engaging students in writing activities often is a challenging task in the EFL classrooms of Nepal. I found two major challenges while implementing the concept of journal writing in my school. 


\section{Initiating journaling}

Journaling is commonly used in EFL classrooms around the world, however, for me initiating journaling in my school was the first challenge. The teachers were found to be confused as to how to help students in writing and how to assess such writing for awarding marks. This daunted them even further as they had to check so many writings besides their daily work (DenneBolten, 2013). For students, writing journals felt like an extra burden apart from doing classwork and home assignments.

\section{Demotivation}

Secondly, a few students were not motivated by writing journals. They felt bored to write the same thing again and again, especially when they could not be reflective. They would find each journal entry just as a record of activity done in the classroom; the same routine activities performed by the teacher and students in the classroom. I observed that some students wrote journals just to achieve grades as the requirement for internal assessment. It could also be challenging when many students demonstrate little reflective thinking in their reflective journals and show less motivation for writing such task (Cisero, 2006).

To minimize challenges, I shared my own experience and aroused interest in teachers and students during the initial phase. Further, teachers in the school allocated certain grades or marks for journaling as a part of internal assessment, which encouraged them to sustain student motivation. Selecting some of the best writings, awarding them and making publication of journals can also minimize the above-mentioned challenges.

\section{Conclusion}

Reflecting on my journey as a student to teacher, I realized that journal writing can perform multifarious tasks in the EFL classroom. First, it enables students to be reflective and confident about their academic work by recalling and writing every day. Journal writing provides students ample opportunity to improve writing skills by using rhetorical devices, appropriate diction and various structures in writing. The study also shows that journal writing helps students to develop flow of the ideas in their writing.

In the same way, journaling becomes a tool for recording (memory box) and expressing students' feelings, emotions, pain and pleasure. For teachers, reflective journals helps establish good rapport with students and facilitates teaching learning process. Likewise, it acts as a mirror for teachers to reflect on their own teaching and helps to improve the teaching practices. Initiating and sustaining motivation in writing might be challenging in a few cases. However, journaling could be one of the most powerful strategies to enhance writing skills and reflective practice in the EFL classrooms of Nepal.

\section{References}

Baxter, S. J. (2009). Journals in the language classroom. English Teaching Forum, $47(4), 22-26$.

Cisero, C. A. (2006). Does reflective journal writing improve course performance. College Teaching, 54(2), 231-236.

Denne-Bolton, S. (2013). The dialogue journal: A tool for building better 
writers. English Teaching Forum, 51(2), 2-11.

Garmon, M. A. (2001). The benefits of dialogue journals: What prospective teachers say. Teacher Education Quarterly, 28(4), 37-50.

Harmer, J. (2007). How to teach English (new edition)? Harlow: Pearson Education Limited.

Heath, G. (1988). Journals in a classroom: One teacher's trials and errors. The English Journal, 77(2), 58-60.

Hipple, M. L. (1985). Journal writing in kindergarten. Language Arts, 62(3), 255-261.

Kintisch, L. S. (1986). Journal writing: Stages of development. The Reading Teacher, 40(2), 168-172.

Shin, S. J. (2006). Learning to teach writing through tutoring and journal writing. Teacher and Teaching: Theory and Practice, 12(3), 324-345.
Thomas, S. (2017). Journalogue: Voicing student challenges in writing through a classroom blog. Journal of Educational Technology \& Society, 20(1), 112-122.

Ur, P. (1991). A course in language teaching: Practice and theory. Cambridge: Cambridge University Press.

\section{Contributor}

Gyanendra Kumar Yadav is a research scholar at Kathmandu University and teaches English language at different colleges in Lalitpur. He is pursuing his M. Phil. in English Language Education from Kathmandu University, School of Education. He is also a life member of NELTA, and has published several journal articles and presented papers in NELTA conferences. His areas of interest include teaching English through literature, teachers' professional development, and critical pedagogy. 


\section{Appendix 1: My journal}

Day 15

10 August, 2015

It was the last day of two years M. Ed. ELT program. We organized a small get-together program and invited all professors. They taught us from the first semester to the fourth. It was a kind of small tribute for what they have done for us. I was little sad since a few professors could not make time for it. But at the same time I was very excited as I had been given responsibility of master of the ceremony $(\mathrm{MC})$. It was really a wonderful experience to have such a gathering. It made me feel like we belong to the same family and I will always be proud to be a part of it. I may go far away once we leave the university, but I will always be connected to our Gurus (teachers).

The academic and professional lives that I have shaped today is because of my Gurus. They guided me in every spheres, inside and outside the classroom. They helped us develop professionally. Therefore, I want to say to my Gurus that:

You helped us to develop our wings and now it is time to fly. No matter wherever I go and whoever I be, I will never forget what you have done to me. I was no one before you came into my life and I will be nowhere without your support. Thank you very much for being the part of my life.

\section{Appendix 2: A students' journal}

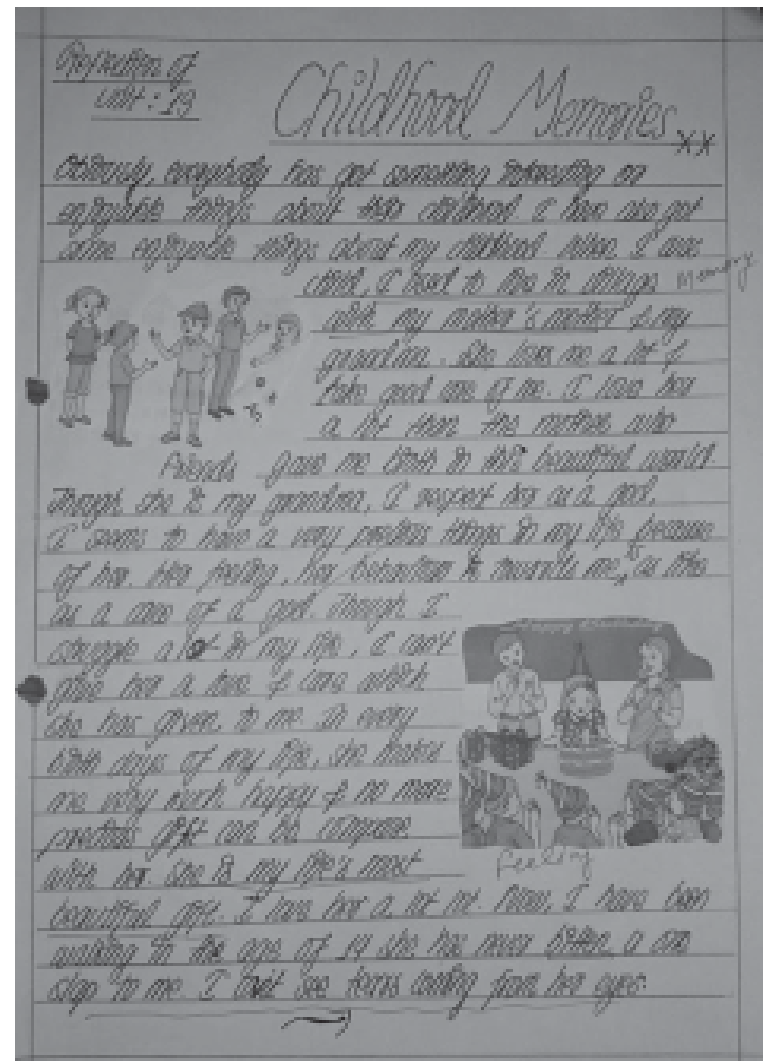

